\title{
Representar lo irrepresentable: las fotografías de Lee Miller en Buchenwald y Dachau
}

\author{
Ainara Miguel SÁEZ de URABAin \\ Universidad del País Vasco UPV/EHU \\ ainara.miguel@ehu.eus
}

Recibido: 22 de enero de 2016

Aceptado: 24 de febrero de 2016

\section{Resumen}

Este artículo propone una reflexión en torno a lo que el historiador Saul Friedländer dio en llamar "los límites de la representación" de las masacres y los genocidios, con el objetivo de aportar pruebas que contribuyan a zanjar el viejo debate sobre la irrepresentabilidad del Holocausto. Para lograrlo, se realizará un análisis textual de cinco de las imágenes más dolorosas que la fotógrafa americana Lee Miller realizara en los campos de concentración nazis de Buchenwald y Dachau, en abril de 1945. La corresponsal de guerra, quien llegó a ser asistente de fotografía, musa y amante de Man Ray, presenció el horror, y si supo representarlo fue, en gran parte, gracias a su mirada surrealista.

Palabras clave: Miller; Holocausto; Shoah; imágenes; representación; horror.

\section{Representing the Unrepresentable: The Photographs of Lee Miller at Buchenwald and Dachau}

\begin{abstract}
This article proposes a reflection on what the historian Saul Friedlander called "the limits of representation" of the massacres and genocides, in order to provide evidence to help settle the old debate about the Holocaust unrepresentability. To achieve this, we will carry out a textual analysis of five of the most painful images that the American photographer Lee Miller realized in the Nazi concentration camps of Buchenwald and Dachau, in April 1945. The war correspondent, who had been Man Ray's assistant photographer, muse and lover, witnessed the horror, and if she knew how to represent it, that was, in a great extent, thanks to its surreal look.
\end{abstract}

Keywords: Miller; Holocaust; Shoah; images; representation; horror.

\section{Referencia normalizada}

Miguel Sáez de Urabain, A. (2016). Representar lo irrepresentable: las fotografías de Lee Miller en Buchenwald y Dachau. Historia y Comunicación Social. Vol 21, número 1, páginas 155-174.

Sumario: 1. Introducción. 2. Estado de la cuestión. 3. Metodología. 4. Resultados. 4.1. Montones de ropa junto al tren. 4.2. Montones de huesos junto al crematorio. 4.3. Prisioneros liberados. 4.4. Pila de cadáveres en el patio. 4.5. Guardias capturados. 5. Conclusión. 6. Referencias bibliográficas. 


\section{Introducción}

El propósito de este trabajo es aportar una reflexión que contribuya, siquiera modestamente, a zanjar el viejo debate sobre los límites de la representación de la Shoah, un debate inconcluso y recientemente reavivado por el estreno de la película húngara El hijo de Saúl, dirigida por László Nemes. Para lograrlo, se analizarán cinco de las más duras fotografías que la corresponsal americana Lee Miller realizara en los campos de concentración de Buchenwald y Dachau.

El debate existe desde siempre, como desde siempre existen las masacres y los genocidios: desde la matanza de los atenienses en la Egina de la Antigüedad clásica hasta las que hoy mismo se están cometiendo en Cachemira (India), en Myanmar (Birmania) o en las zonas de influencia del autoproclamado Estado Islámico, pasando por los genocidios perpetrados en la Camboya de los jemeres rojos (entre 1975 y 1979), en la Argentina de la dictadura militar (entre 1976 y 1983), en la Ruanda de 1994 o en la Srebrenica de 1995. Y siempre fueron tan atroces que terminaban considerándose indescriptibles, irrepresentables, porque, en palabras de los historiadores argentinos Burucúa y Kwiatkowski, "se trata de hechos extremos, que ponen a prueba las categorías usuales de conceptualización" (2014: 14), son crímenes que no podemos concebir sin destruir nuestro modo de ver el mundo. Y el hecho más extremo entre los extremos es, cómo no, el Holocausto.

De ahí que la polémica en torno a la representación de la Shoah haya hecho correr ríos de tinta en Francia desde los años cincuenta. Se recrudeció después, a mediados de los ochenta, cuando Claude Lanzmann rechazó frontalmente incluir fotografías de los lager en su película Shoah por entender que el Holocausto era (y es) irrepresentable; y en el segundo milenio, al afirmar Georges Didi-Huberman en su ya clásico estudio Imágenes pese a todo (2003) que el Holocausto no sólo era representable, sino que había sido representado en las fotos que un sonderkommando, jugándose la vida, había tomado desde el interior de una cámara de gas de Auschwitz.

Estas imágenes de Lee Miller nada tienen que ver con las del sonderkommando. Miller no retrató la masacre mientras estaba sucediendo, sino que lo hizo después, cuando todo había acabado; tampoco arriesgó su vida por revelar aquel espanto. Porque ella no era un judío griego prisionero en Auschwitz tomando fotos de la incineración de cadáveres desde el interior de un crematorio, sino una fotógrafa americana que, como otros muchos, cumplía las órdenes del presidente Eisenhower quien, ansioso por mostrar al mundo occidental la heroicidad de los aliados, hizo llamar a reporteros de medio mundo.

Existen, pues, millones de fotografías de los campos de concentración tomadas por los liberadores. Algunas muy famosas, como las de Georges Rodger en el campo de Bergen-Belsen o las de Margaret Bourke-White ${ }^{1}$ en el mismo Buchenwald. Pero, así como Miller no se parecía al judío griego miembro del sonderkommando dispuesto a morir por cuatro fotos, tampoco se parecía al resto de corresponsales. Lee Miller 
era sólo una fotógrafa americana, sí, pero una fotógrafa americana con una curiosa historia.

Miller nació en abril de 1907 en Poughkeepsie, una pequeña ciudad del estado de Nueva York, y murió setenta años después, en una granja inglesa. Fue una mujer brillante. Fue hermosa, demasiado hermosa, honesta, curiosa, demasiado curiosa, valiente, temeraria incluso. Vivió más de una vida -modelo de moda en Nueva York, musa surrealista en París, fotógrafa de guerra, cocinera gourmet- y las vivió intensamente; si hubiera algo capaz de resumirlas todas, eso sería su mirada.

Con veinte años, sus preciosos ojos azules posaron para los grandes fotógrafos de su tiempo, Edward Steichen, George Hoyningen-Huene y Arnold Genthe, e iluminaron las páginas de la edición americana de la revista Vogue. Poco después, ya en el estudio parisino de Man Ray, la fotografía en blanco y negro de uno de ellos sirvió para convertir un vulgar metrónomo en una obra de arte surrealista.

Pero eso fue después de que Miller, quién llegó a ser asistente de fotografía, musa y amante de Man Ray, dejara al artista para volver a Nueva York y montar su propio estudio. Desolado, Man Ray, creó una segunda versión de Objet indéstructible, una pieza de 1923 a la que cambió el ojo original por el de Miller a la vez que le añadía unas inquietantes instrucciones: "Recorte de una fotografía el ojo de la persona amada a la que ya no volverá a ver. Fije el ojo en el péndulo de un metrónomo y regule la pesa para ajustar el tempo. Déjelo funcionar hasta el límite de su resistencia. Con un martillo, intente destruirlo todo de un solo golpe".

Como se ve, la historia de amor entre Miller y Man Ray no terminó demasiado bien. Miller y el movimiento surrealista, sin embargo, se mantendrían unidos para siempre. En aquellos años, la hermosa rubia apareció en Le sang d'un poète (1930), una película de Jean Cocteau, haciendo de estatua, con los ojos cerrados. Y fue retratada por Picasso en no menos de seis ocasiones.

Pronto Miller se cansó de ser mirada y quiso dejar de ser una bella escultura. Con una gran determinación, pasó de bonita modelo a famosa fotógrafa, de objeto de deseo a artista. Miembros de la alta sociedad neoyorkina esperaban impacientes la cita para poder retratarse en su estudio de Manhattan, donde trabajó hasta que el amor, en forma de primer marido, la llevó a Egipto.

La Segunda Guerra Mundial estalló cuando la fotógrafa ya estaba aburrida de ver pirámides y desiertos, y locamente enamorada del pintor y coleccionista inglés Roland Penrose. Su mirada surrealista registró vívidamente la devastación provocada por la fuerza aérea alemana desde el cielo londinense. Cientos de bombarderos trataron de destruir Londres durante un infierno que duraría casi dos meses. Después de aquello, Miller estaba dispuesta a partir al frente. Vogue, la misma revista que había lucido sus ojos en portada, publicaría a partir de ahora sus vistas del horror: Saint Malo, París, Buchenwald, Dachau... todos esos lugares donde la guerra hizo estragos.

No obstante, las fotografías de guerra de Miller son poco convencionales. En general, salvo cuando no tenía más remedio -como en los lager-, sus imágenes evitan las 
peores escenas de la guerra, recreándose en los pequeños detalles cotidianos: bomberos, gente trabajando en las fábricas de munición, hombres y mujeres durmiendo en las estaciones de metro londinenses, ciudades y pueblos bombardeados, soldados charlando, enfermeras descansando, prisioneros fumando, la propia fotógrafa bañándose en la bañera de Hitler...

Las cinco imágenes fotográficas analizadas en este trabajo son, por tanto, algunas de sus imágenes más horribles. Fueron tomadas justo después de la liberación de los campos de concentración de Buchenwald y Dachau, en abril de 1945, y basta una ojeada para darse cuenta de que son tan aterradoras como inusuales.

Son fotografías documentales, sí, pero también artísticas. Están realizadas rápidamente y en circunstancias difíciles, pero su composición es sobria, sus significados infinitos. Imágenes connotativas, evocadoras, intimistas. Estas cinco fotografías no son otra cosa que la mirada de su autora; una mirada tan hermosa, honesta, valiente y surrealista como ella, que supo captar el horror del Holocausto en toda su crudeza.

Antes de ver las fotos, sin embargo, es preciso aclarar dos cuestiones. La primera que, aunque estas imágenes sean hoy, indudablemente, imágenes del Holocausto, cuando fueron tomadas no eran más que fotografías de guerra. Es decir, Miller fotografío el Holocausto sin saber qué demonios estaba fotografiando. Era consciente del horror que veían sus ojos, pero todavía no sabía nada del plan de Hitler para aniquilar a todos los judíos europeos.

De hecho, en ningún momento de su reportaje se refiere a los muertos como a judíos. En sus textos habla de cadáveres de franceses, belgas, rusos, polacos, británicos, americanos y veintidós países más (Miller, 2005: 165). En parte tenía razón, pues, justo al final de la guerra, cuando las tropas americanas y británicas liberaron los campos del oeste, sólo uno de cada cinco supervivientes era judío. Al saber que el final de la guerra estaba cerca, los nazis apresuraron la Solución Final, y mataron a 10.000 judíos de ambos campos pocos días antes de la liberación.

Así, como escribe Sliwinski, "algo que todavía no había sido entendido tenía que ser representado" (Sliwinski, 2010: 392). Y la Rolleiflex de Miller debía encuadrar escenas inconcebibles aún, acontecimientos que no podía asimilar completamente, imágenes que, pese a los cinco años de guerra que sus ojos venían soportando, sólo podía mirar anestesiada con alcohol.

La segunda cuestión que debe ser aclarada tiene que ver con la audiencia a la que estas fotos iban dirigidas, las lectoras de Vogue. Mujeres civiles, inglesas y americanas, compraban la revista, en cuyas páginas encontraban los reportajes de guerra de la famosa corresponsal, junto a fotografías de moda, anuncios de maquillaje e imágenes de las casas de los ricos y famosos. El horror parecería más horrible aun, si cabe, rodeado como estaba de páginas y páginas dedicadas a la belleza.

Estas imágenes fueron, pues, fotografías de guerra realizadas por Lee Miller para las lectoras de Vogue. Su autora no supo hasta muchos años después que lo que en realidad fotografió fue la Shoah. El intenso debate en torno a la representación 
del Holocausto y la legitimidad de mostrar lo inimaginable avivado por Georges Didi-Huberman, Gerard Wajcman y Claude Lanzmann vino mucho después.

\section{Estado de la cuestión}

Todo empezó con una frase del filósofo alemán Theodor Adorno: "Escribir poesía después de Auschwitz es un acto de barbarie" (1983, p. 34). Para él, Auschwitz había significado el exterminio no solo de millones de personas, sino también de la misma idea de humanidad. Por eso, concluía, el arte ya no era posible.

Después de Auschwitz ha habido, no obstante, mucho arte cuyo objetivo es, precisamente, dar a conocer, mostrar el Holocausto en todo su horror. Ahí están, por ejemplo, la extraordinaria trilogía literaria de Primo Levi -Si esto es un hombre, La tregua y Los hundidos y los salvados- y la arrebatadora película de Claude Lanzmann, Shoah.

Shoah es quizá, como escribió Marcel Ophüls, la película más importante sobre el Holocausto jamás realizada. Un film clave. La misma Simone de Beauvoir, amante del director durante años, sentenció: "Nunca hubiera imaginado una combinación así de belleza y horror" (Liebman, 2007: 46). Una combinación de belleza y horror que llevó a Lanzmann a recorrer catorce países durante once años y acabar montando una película de más de nueve horas de duración; una obra de arte cuyo objetivo era, en palabras de su autor, comunicar a la audiencia algo de la degradación y el horror experimentado por millones de inocentes.

Lanzmann, al contrario que Adorno, no reniega del arte pero sí de los fragmentos de películas de archivo y de las fotografías históricas de la Shoah, que no aparecen en su película. Una notoria ausencia que lo alinea con Sartre, quien escribió que los pintores del Holocausto tenían dos opciones: traicionar la pintura negándole la belleza o, si a pesar de todo su trabajo se veía bello, traicionar la ira y la tristeza de los hombres. De cualquier manera, el resultado era una traición.

Se extendió así entre los expertos la idea de que estas imágenes, más que ayudar a entender, lo que hacían era provocar un abismo ético. Para el director, y para muchos de sus seguidores -Gérard Wajcman, Élisabeth Pagnoux-, esas imágenes sólo pueden funcionar como velo o escudo, incitando un falso sentido de conocimiento, a la vez que protegen al espectador del verdadero horror. Su rechazo a utilizar las fotografías de los campos de la muerte fue, argumenta Lanzmann, la única manera de representar lo que es, de hecho, inimaginable. "El Holocausto", escribe Lanzmann, "es único porque creó un círculo de llamas a su alrededor, un límite que no puede cruzarse puesto que el horror en grado absoluto no puede ser comunicado" (Ibid: 54). Así, las opciones formales de Shoah sirvieron de coartada a todo un discurso sobre lo inimaginable, lo incomunicable, lo irrepresentable.

Otros críticos, Georges Didi-Huberman se sitúan en otra posición. Piensan que el horror puede y debe imaginarse y que las fotografías ayudan. Muchas veces, además, 
el contraste entre el horror y la belleza no hace sino magnificar el primero. En Imágenes pese a todo (Didi-Huberman, 2003), el profesor francés ofrece una atenta lectura de cuatro fotografías que miembros del Sonderkommando tomaron en Auschwitz en agosto de 1944. Didi-Huberman insiste en que los esfuerzos de los prisioneros por arrebatar esas fotos a la desgarradora realidad nos obligan a mirar y a imaginar Auschwitz por nosotros mismos. En sus palabras, las cuatro fotos son cuatro refutaciones arrebatadas a un mundo que los Nazis querían silenciar y oscurecer, dejándolo sin palabras ni imágenes. Son, además, pre-narrativas, formadas antes de que las ideas sobre lo que significaban los campos pudieran formarse siquiera. Porque las imágenes ofrecen la posibilidad de imaginar lo inimaginable y aciertan donde las palabras fallan:

Porque en cada producción testimonial, en cada acto de memoria los dos-el lenguaje y la imagen- son absolutamente solidarios y no dejan de intercambiar sus carencias recíprocas: una imagen acude allí donde parece fallar la palabra; a menudo una palabra acude allí donde parece fallar la imaginación. La 'verdad' de Auschwitz, si es que esta expresión tiene algún sentido, no es ni más ni menos inimaginable que indecible. Si el horror de los campos desafía la imaginación, ¡cuán necesaria nos será, por lo tanto, cada imagen arrebatada a tal experiencia! (Ibid: 49).

Auschwitz no puede ser, por tanto, indecible, ni irrepresentable, ni inimaginable, ni impensable, puesto que fue pensado, imaginado, representado y ha sido dicho, contado, mil y una veces.

Pese a todo, hay críticos que siguen prefiriendo cerrar los ojos a esta realidad. El psicoanalista francés Gérard Wajcman, por ejemplo, sigue convencido de que "la Shoah existió y permanece sin imagen"; de que es incluso algo "sin rastros visibles e inimaginable"; el "objeto invisible e impensable por excelencia"; la "producción de algo Irrepresentable", etc. (Wajcman, 1998: 21, 23, 236,239).

Pero en el mismo Auschwitz funcionaron dos laboratorios de fotografía y, aunque al acercarse el final de la guerra los nazis trataron de destruir el mayor número posible de fotografías, los prisioneros hicieron lo posible por salvarlas, de modo que hoy en día quedan alrededor de cuarenta mil imágenes de Auschwitz. A medida que los demás campos fueron liberados, fueron tomadas más y más fotografías. Sólo el ejército americano realizó más de un millón de instantáneas.

No parece justo, pues, que tanto Didi-Huberman como cualquier investigador que trate "simplemente [...] de ver para saber mejor" (Didi-Huberman, 2003: 90), puede ser acusado de fetichista y voyeur, de usurpar el papel de testigo y, lo que es peor, de destruir la mirada y anular la memoria. Sostiene Wajcman que la pasión de Didi-Huberman por la imagen, su fe en ella, es "íntimamente cristiana", pero es él quien recuerda a san Bernardo, el místico del siglo XII que, al condenar los monstruos esculpidos en las columnas o en los capiteles de las iglesias románicas -representaciones que consideraba moralmente reprobables-, no daba sino muestra de sucumbir a su fascinación (Eco, 2004: 12). 
Indudablemente, tampoco hay que caer en la tentación de entender las palabras de Wajcman y Lanzmann de forma literal. A pesar de sus frases tan rotundas, ellos saben que sí hay imágenes, millones de imágenes, de la Shoah. Deciden evitarlas porque, a su juicio, son sospechosas e inadecuadas; no valen nada. La mayoría, como las de Miller, fueron tomadas por los ejércitos de liberación cuando todo había acabado, por lo que sólo pueden retratar algunos de los resultados de la brutalidad nazi, pero jamás la brutalidad en sí. Tienen, además, el inconveniente, de ser "imágenes sin imaginación" (Liebman, 2007: 76), imágenes inexactas que, con intención o sin ella, transforman la masacre de los judíos en algo mucho menos trascendental y mucho más comprensible de lo que fue.

Precisamente para evitar mitigar y hacer inteligible aquella tragedia Lanzmann renuncia en Shoah a la narración cronológica, y opera uniendo varias narrativas, pequeñas y locales, que van superponiéndose unas a otras y resonando ininterrumpidamente de un extremo a otro del metraje. Pensándolo bien, ¿no es eso precisamente lo que hacen las fotografías?

En su introducción a la película, Stuart Liebman escribe: "Ningún entrevistado por Lanzmann está en posición de hablar sobre 'el Holocausto', esa abstracción global utilizada por los historiadores para referirse a la suma de todos aquellos acontecimientos. Todos son testigos de un único aspecto- pero a menudo un aspecto extraordinariamente revelador- del aterrador conjunto" (Ibid: 71). ¿No es eso precisamente lo que sucede con las fotografías?

Claro que no hay ninguna película, ninguna imagen que por sí misma explique "el aterrador conjunto". Claro que las películas, las imágenes de la Shoah son subjetivas e inexactas, parciales e incompletas. Como los testimonios de los supervivientes, como los testigos de Lanzmann. Pedirle a una imagen que diga "toda la verdad" es, como dice Didi-Huberman, pedirle demasiado. Pero, aunque no podamos pedir a las imágenes que digan toda la verdad sobre el Holocausto, ¿no podríamos conformarnos con el hecho de que prueban su existencia?

Las cuatro fotografías de agosto de 1944 no dicen 'toda la verdad', por supuesto (hay que ser muy inocente para esperar eso de lo que sea, las cosas, las palabras o las imágenes) [...]. Pero son para nosotros -para nuestra mirada actual- la verdad en sí misma, es decir, su vestigio, su pobre andrajo: lo que queda, visualmente de Auschwitz (Didi-Huberman, 2003: 65).

\section{Metodología}

Como es sabido, los nazis rodearon la "Solución final" de un secretismo total. Querían hacer desaparecer a los judíos, sí, pero también las huellas de sus crímenes, de ahí que se dedicaran a no "dejar ningún rastro", a "hacer desaparecer cualquier resto" (Ibid: 40, 41).

En palabras de Didi-Huberman, los alemanes hicieron desaparecer los cuerpos de sus víctimas, las herramientas de desaparición -destruyendo las cámaras de gas, los 
crematorios y el resto de las instalaciones que servían para consumar el genocidio-, y los archivos, la memoria de la desaparición -quemando los documentos sobre los detenidos-. En Treblinka, por ejemplo, los cadáveres fueron exhumados de las fosas comunes e incinerados en unos enormes braseros. Los huesos fueron triturados y enterrados de nuevo en las mismas fosas, junto con las cenizas. Árboles y semillas fueron plantados en la tierra manchada de sangre.

De ahí que el propio Lanzmann afirme que empezó su película precisamente con la imposibilidad de contar esta historia. Los rastros habían desaparecido, no había nada de nada, y tuvo que hacer una película sobre la base de esa nada; construir, como dice un poco más adelante, un acontecimiento originario con "los rastros de los rastros" (Liebman, 2007: 44, 46).

¿Y qué son las fotografías de Miller sino "los rastros de los rastros"? Sorprende que los expertos de hoy hayan prescindido tan rápidamente de los textos de Barthes. Porque las imágenes, debido a su misma naturaleza técnica, son índices, son huellas de lo real: "la fotografía es literalmente una emanación del referente" y, por tanto, "testimonio de que lo que veo ha sido", "certificado de presencia" (Barthes, 1980: $142,145,151)$.

La fotografía es una huella de lo real porque implica que, durante un instante -el instante de la exposición propiamente dicha-, lo fotografiado estuvo allí. Es cierto que antes y después de ese instante hay mucho margen para la manipulación, pero durante ese instante el referente tuvo que estar ahí para dejar su huella de luz. Como escribió el mismo Barthes: "la fotografía jamás miente: o mejor, puede mentir sobre el sentido de la cosa, siendo tendenciosa por naturaleza, pero jamás podrá mentir sobre su existencia" (Ibid: 151).

Los nazis intentaron borrar las huellas de sus crímenes, pero no lo consiguieron, así que, en este punto, tanto Didi-Huberman como Lanzmann exageran. Los alemanes, en su desesperada huida, se dejaron testigos, cadáveres, huesos, campos de concentración, cámaras de gas, crematorios, fragmentos de película y millones de fotografías que un tiempo después, si no para hacerlo inteligible, servirían para probar que pasó lo que pasó.

Las fotos de Miller están entre las miles de imágenes arrebatadas a esa realidad demencial. La corresponsal entró en Buchenwald y Dachau en abril de 1945. Sus reportajes -fotos y textos- fueron publicados en las ediciones británica y americana de Vogue. El titular que acompañaba su historia sobre los campos de concentración -aparecido en el especial "Victoria" en junio de 1945- rezaba: "BELIEVE IT". Imposible dudar de que las fotos funcionaran como testimonio, como prueba para una población escéptica.

No obstante, el miedo a que el propio testimonio resultara incomprensible, a que fuera juzgado como absurdo, increíble, inimaginable, etc. no era infundado. De hecho, como escribió Hannah Arendt, los nazis "estaban totalmente convencidos de que una de las probabilidades de éxito de su empresa residía en el hecho de que nadie 
del exterior podría creérselo". Para su desgracia, encontramos las huellas, encontramos las fotos.

Las encontramos y las estudiamos como si fueran textos, textos artísticos, en realidad. De ahí que se plantee una lectura estética, partiendo de que es ella la que impone la manera en que todas las demás deben hacerse (Talens, 1980). Entre todos los métodos de interpretación de los estudios visuales, escogemos, pues, aquellos orientados al texto, entre los que destacan la semiótica estructural de A. J. Greimas y la Escuela de París. Nos aferraremos, por tanto, al texto, a las imágenes, y a su trasfondo cultural y artístico.

\section{Resultados}

Las fotografías, las huellas del horror escogidas para este trabajo son sólo cinco de las 74 imágenes de Buchenwald y Dachau recogidas en el archivo online de Lee Miller $^{2}$. Pese a que evitan algunas de las mayores atrocidades -en ellas no se ven cámaras de gas ni hornos crematorios-, no representan otra cosa que el horror. Son escenas terribles, espantosas, que causan una aversión intensa y profunda. Pero son también escenas soberbiamente compuestas, capaces, si no de comunicar la Shoah, sí de sugerir el alcance de aquel horror.

4.1. Montones de ropa junto al tren

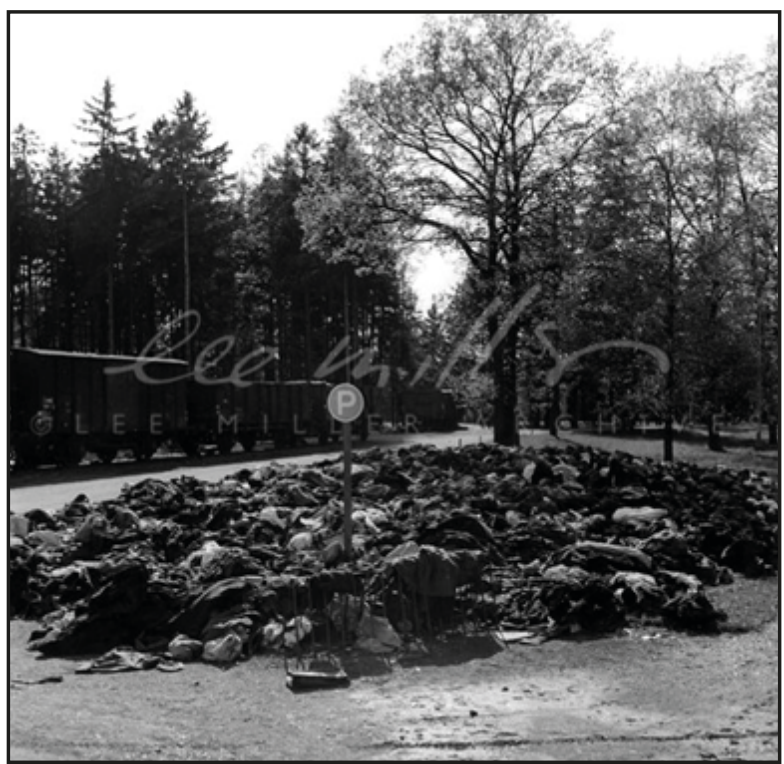

(C) Lee Miller Archives, England 2014. All rights reserved. www.leemiller.co.uk. Esta fotografía se titula Montones de ropa y pertenencias junto al tren (Piles of Clothes and Belongings Alongside Train) y fue realizada en el campo de concentración de Dachau, Alemania, en abril de 1945. 
Dachau fue liberado el 29 de abril de 1945 por el ejército americano. Lee Miller entró con David Scherman -fotógrafo de Life y amigo íntimo- la noche del 30, cuando las huellas estaban frescas todavía. Dachau no era un campo de exterminio como Auschwitz, Treblinka o Sobibor, sino una prisión para "lo mejor de lo mejor" donde la mayoría de los prisioneros eran presos políticos. Pero lo que soldados y periodistas se encontraron al llegar fue el mismísimo infierno.

El 28 de abril, un día antes de la liberación, había llegado al campo el último transporte de prisioneros, un tren con unos 3.000 detenidos evacuados de Buchenwald el 7 de abril: el tren de la muerte. Cuando los soldados abrieron las puertas, descubrieron que los vagones estaban llenos de cadáveres harapientos, sucios de sangre y excrementos. Menos de veinte personas seguían con vida. Las vistas y el hedor debían de ser tan insoportables que muchos de los soldados, tipos realmente duros, prorrumpían en llanto o vomitaban. Miller, sin embargo, se subió al tren y cruzó la frontera entre la vida y la muerte, llevando consigo al espectador (Sliwinski, 2010: 401). No hay duda de que era brava.

A ella, más que los muertos, lo que le repugnaba eran las contradicciones. En sus textos, ricos, impresionistas y bastante más irónicos que las imágenes, detalla que en Dachau, aparte del tren, había una granja de conejos donde los animales, mucho mejor alimentados que los prisioneros, lucían gordos, limpios y felices.

Los conejos tenían más sitio que los prisioneros, que dormían hacinados en las literas de los barracones inmundos donde, al llegar los americanos, yacían los hombres demasiado débiles para celebrar la victoria. En los pocos minutos que estuvo haciendo fotos, escribe Miller, dos hombres aparecieron muertos y fueron arrastrados fuera y arrojados al montón: "A nadie pareció importarle más que a mí” (Miller, 2005: 182).

El reportaje de Miller describe también los montones de ropa que aparecen en la imagen, una fotografía de guerra nada convencional. Se trata de un plano general que envuelve la ropa, el tren y los árboles de Dachau. La mirada de Miller deja al espectador fuera de la escena, en el camino, justo frente a la señal de aparcamiento y el árbol que, junto con el propio espectador y los demás árboles, son los únicos en vertical. El resto, la ropa, los cachivaches, están tirados en el suelo, y el contraste entre su disposición horizontal y los árboles evoca la espiritualidad y el sosiego de un cementerio.

Casi podemos ver el silencio, porque esta imagen no es sólo la imagen de unos mugrientos harapos amontonados junto a un tren; es la imagen de la ausencia, del vacío que dejaron sus dueños. Miramos el triángulo formado por la pila de ropa en el suelo, alzamos la vista hacia el árbol que domina uno de sus vértices y pensamos: ¿de quién son esas ropas?, ¿serán las ropas de civil de quienes fueron ejecutados inmediatamente al llegar?, ¿serán las ropas de prisionero de los muertos?

Los montones de ropa que invaden el campo nos hablan de la implacable desnudez de los prisioneros, de la enajenación de la que eran objeto nada más llegar. Todo lo que tenían les era arrebatado, sus cosas, las prendas que vestían e incluso el pelo que 
cubría sus cuerpos. Desposeídos ya del pudor, a los prisioneros no podía quedarles sino la conciencia de haberlo perdido todo, salvo la vida.

La señal de tráfico indica otras dos cosas. La primera, que el espacio que ocupaban los trapos era un espacio reservado al estacionamiento; la segunda, que las expropiaciones se estaban haciendo ordenadamente. No se trataba, pues, de robos improvisados. Esto era otra cosa; eran robos pensados, medidos, intencionados; robos organizados de forma sistemática y eficiente.

Esto, unido a la estaticidad de la imagen, nos hace comprender que no estamos ante una instantánea sino ante el principio de un cuento largo y complejo. El eco de las palabras de Filip Müller -un judío checo superviviente de las cinco liquidaciones del Sonderkommando de Auschwitz- en Shoah resuena en nuestros oídos: "Para cualquiera que hubiera cruzado el umbral del campo era demasiado tarde. Ninguno podría ser salvado".

\subsection{Montones de huesos junto al crematorio}

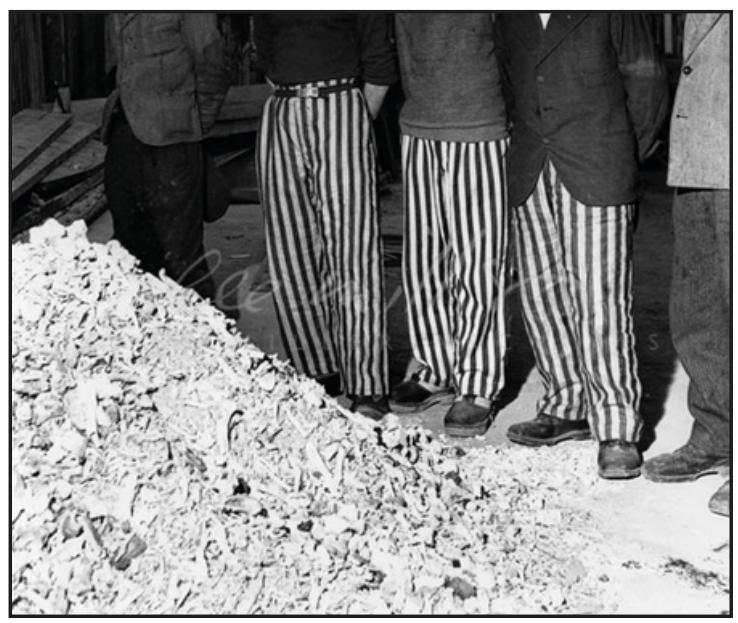

C) Lee Miller Archives, England 2014. All rights reserved. www.leemiller.co.uk

Miller tomó esta imagen fotográfica, titulada Hombres contemplan los huesos calcinados de sus compañeros de prisión (Men Contemplate the Charred Bones of Their Fellow Prisoners), en Buchenwald, Alemania, en abril de 1945, unas pocas semanas antes de haber estado en Dachau. La foto, publicada en la edición americana de la revista Vogue en junio del mismo año (US Vogue, June 1945: 103), muestra una pila de huesos carbonizados fuera del crematorio de Buchenwald. Tras ellos pueden verse las piernas de los prisioneros recién liberados.

Esta imagen, más abstracta que la anterior en el plano formal, es bastante más concreta en el plano de contenido. Porque ya no se trata de representar las ropas de los prisioneros ausentes, sino de mostrar sus huesos que, aunque reducidos a cenizas, 
están bien presentes. La metonimia de la fotografía anterior deja paso a un par de sinécdoques; la parte por el todo, los huesos por los muertos, las piernas en pijama de rayas por los vivos.

Encuadre y composición vuelven a encargarse de subrayar la construcción artificial de la imagen, esta vez con mucha más fuerza. Lejos de una representación clásica de la guerra, Miller mira en picado, negando al espectador la visión de los rostros de los supervivientes y acercándolo a los huesos de los que han muerto, poniéndolo en su lugar.

Hay alguna repetición que revela la cuidada organización del cuadro: los tres pares de piernas, las líneas de sus pantalones rayados, las dos formas piramidales formadas una por la pila de huesos y la otra por la visión de las piernas de los prisioneros. Todo lo demás no es más que contraste. Contraste entre la horizontalidad de los huesos y sus formas irregulares, y la verticalidad de los pijamas y sus formas regulares; entre la luz de la parte inferior de la imagen y la oscuridad que rodea la parte superior. Un contraste, una tensión, que se extiende de la expresión al sentido y hace de la foto una imagen desgarradora. Porque en esta fotografía se superponen dos platos totalmente opuestos: los cuerpos reducidos a cenizas contra los cuerpos de los supervivientes. La muerte y la vida como las dos caras de la misma moneda, como el ying y el yang, al que la combinación de blancos y negros de esta foto remite sin proponérselo.

Y no sólo las imágenes de Miller, también sus palabras parecen encontrar el sentido en los contrastes. Su reportaje sobre Alemania comienza con la incongruencia entre el bello paisaje y la locura criminal de sus habitantes, y continúa destacando la repugnante desproporción entre los cuerpos de los cadáveres consumidos y el de un guardia nazi que, tras suicidarse, había sido arrojado al montón "donde parecía sorprendentemente grande, el bien alimentado hijo de puta" (Miller, 2005: 165).

Curiosamente, este mismo contraste puede verse en Shoah, entre el horror de los crímenes que describen los supervivientes y la belleza de los escenarios donde esos mismos crímenes tuvieron lugar. Imposible olvidar el principio de la película, en Chelmo, Polonia, cuando la cámara se pasea por un silencioso y bello bosque surcado por un río plateado, mientras un testigo cuenta que era allí donde los alemanes quemaban 2.000 judíos al día. 


\subsection{Prisioneros liberados}

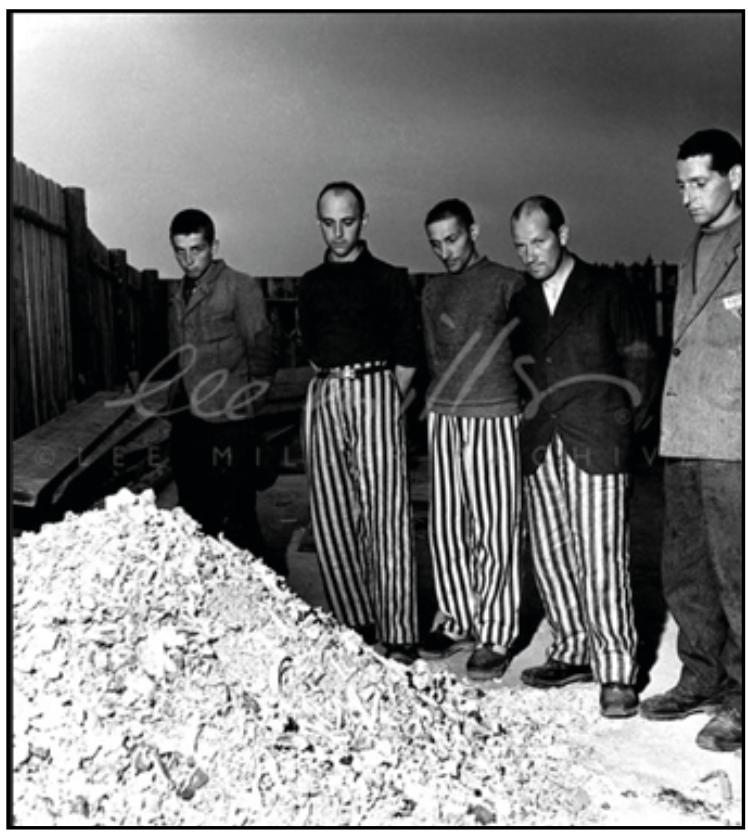

(C) Lee Miller Archives, England 2014. All rights reserved. www.leemiller.co.uk

La tercera fotografía se titula Prisioneros liberados con restos humanos (Liberated Prisoners with Human Remains) y fue tomada, como la anterior, en el lager de Buchenwald en abril de 1945, y publicada en Vogue (US Vogue, June 1945:103) dos meses después.

El encuadre de la imagen anterior se abre para dar paso a una imagen que parece bastante más corriente, hasta que nos topamos con la mirada de los supervivientes. De repente, los ojos de los detenidos se cruzan con los nuestros recordándonos la presencia de la cámara y negando, de paso, que estén ahí sólo para ser mirados. Los del segundo por la derecha son los más comprometedores. Estratégicamente situados e iluminados, pesan en la composición casi tanto como la alta y luminosa montaña de huesos de la que contribuyen a desviar la mirada. Y nos hablan. Del trauma vivido, del alivio de sobrevivir tras haber sido testigos de tanta muerte, de la vergüenza y la culpa de haberse salvado, de la dura batalla que acababan de librar, de la alegría que querían sentir y no podían... quién sabe.

Miramos a los supervivientes y queremos pensar que la supervivencia era la regla de los campos. Pero no. Como bien cuenta Primo Levi, la supervivencia no era la regla, sino la excepción. De ahí que unos pocos salvados claven sus ojos en los hundidos y nos miren después, ¿cómo?, ¿con dolor?, ¿con alivio?, ¿con culpa?, ¿con vergüenza? 
Uno se lo está preguntando todavía cuando, al fijarse en la ropa de los presos, se da cuenta de que no está tan raída como cabría esperar. Si exceptuamos los tres pantalones de rayas, el resto son zapatos, chaquetas y jerséis en aparente buen estado. Esto nos hace pensar que quizá sean ropas cambiadas a los muertos o arrebatadas a los guardias, y nos pone a la vista la dura batalla por la supervivencia entablada entre los prisioneros:

En este caso (cuando se organizaban transportes de enfermos), se examinaba con indisimulada curiosidad a los 'musulmanes' que partían, para comprobar si sus abrigos o zapatos estaban en mejor estado que los de uno y, en tal caso, cambiárselos. Al fin y al cabo, su suerte ya estaba echada. Sin embargo, los que permanecían en el campo y eran capaces de trabajar debían aguzar sus recursos para incrementar las menguadas posibilidades de supervivencia. No cabía ni un grano de sentimentalismo (Frankl, 1947: 79).

Nuestros ojos se encuentran, pues, con los ojos de hombres endurecidos, que habían perdido los escrúpulos. Como escribió Primo Levi: “[...] nadie está autorizado a juzgarlos, ni los que conocen la experiencia de los lager ni, aún menos, los demás" (Levi, 1986: 58). Pero, ¿detectamos una cierta frialdad en sus rostros?, ¿será que nos miran con desdén?

Por otra parte, aunque los prisioneros parezcan seguir encerrados -están rodeados por un recinto cerrado, el patio del crematorio, que no deja de evocar las alambradas-, hacía ya varios días que habían sido liberados, ¿nos miran acaso con alegría?

Sabemos, además, por los escritos de Miller, que el General Patton "invitó" a unos 2.000 alemanes, hombres y mujeres de todas las edades, a visitar Buchenwald. Ya que nunca habían oído hablar de las brutalidades del campo, debió de decir el General, tenían que verlas. Según la fotógrafa, la mayoría se desmayaba, pero unos pocos según mostrándose arrogantes. ¿Es posible que hubiera "turistas" alemanes detrás de la cámara?, ¿podría el prisionero más joven estar lanzándoles una mirada acusadora? 
4.4. Pila de cadáveres en el patio

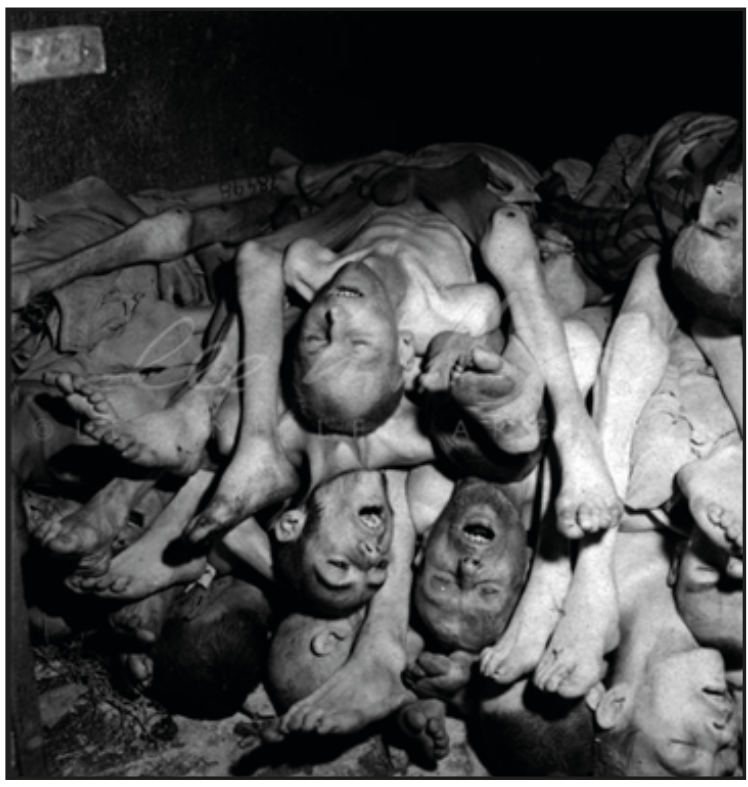

(C) Lee Miller Archives, England 2014. All rights reserved. www.leemiller.co.uk

Y Lee Miller hizo lo que tenía que hacer, lo que cualquier corresponsal de guerra hubiera hecho: sacar las fotografías que probaban la existencia de pruebas, fotos que no eran sino "las huellas de las huellas", otra vez. Los cadáveres estaban allí y la fotógrafa debía certificar su presencia, eso era así; lo único que podía decidir era cómo usar la cámara y esa decisión, como decía Godard, era una cuestión moral. Miller estaba ante un montón de cadáveres, una escena desoladora, y lo único que podía hacer era decidir cómo la contemplarían sus lectores.

Decidió cerrar el encuadre de manera que la pila de cadáveres pareciera no tener fin, y acercarse a los muertos; una cercanía que no sólo es física sino también emocional, que crea un espacio íntimo y promueve la identificación. Porque todos esos rostros a los que vemos del revés, con los ojos cerrados y las bocas abiertas, con sus cabezas entre los pies descalzos de los demás, no son figuren ${ }^{3}$, como pretendían los alemanes, son hombres; aunque sus brazos -ver la esquina superior izquierda de la imagen- estén numerados.

Como es sabido, los nazis pretendían reducir aquellos seres humanos a cosas inhumanas, a cosas sin cuerpo ni alma o, como escribió Arendt, "a mera materia". La misma autora insistía en que los campos de concentración aniquilaban la voluntad y la dignidad de los hombres, en un oscuro intento de aniquilar el mismo concepto de 
ser humano. En el lager se concedía tan poco valor a la vida humana, que los mismos prisioneros tenían el corazón endurecido.

$\mathrm{Y}$ es que los nazis les habían desnudado, matado a trabajar y reducido a cenizas. Pero antes de todo eso, les robaban la identidad. En el momento del ingreso, los detenidos eran despojados de sus documentos personales $\mathrm{y}$, a cambio, recibían un número que les sería tatuado en la piel; en la jerga del lager se conocía como himmlisque Telefonnummer, el número de teléfono celestial: "Los hombres sólo contaban por su número de prisionero. Es más, se convertían en un 'número': estar vivo o muerto carecía de importancia, porque la vida de un 'número' resulta completamente irrelevante. Y todavía importaba menos lo que se escondía detrás de la existencia de aquel número: su destino, su historia, su mismo nombre..." (Frankl, 1947: 79).

Los hombres de la imagen, sin embargo, pese al número en el antebrazo, son hombres. Puede que los alemanes trataran de destruir al hombre, pero las imágenes de Miller son profundamente humanas. El plano corto hace que el espectador se sienta cerca de los muertos, le obliga a mirar esas bocas, esos ojos que son como los suyos. Es imposible evitar un escalofrío.

Pero la identificación explica el estremecimiento sólo en parte. Porque hay otro elemento, un elemento formal, que añade horror a una imagen ya horrible de por sí: su simetría, su regularidad. Evidentemente, la insólita disposición de los cuerpos, es decir, el hecho de que estuvieran así colocados, era cosa de los nazis, que organizaban la muerte de forma sistemática, eficiente -así colocados los cuerpos ocupaban menos espacio-, con una frialdad que resulta casi tan aterradora como la propia muerte. El hecho de que las dos rodillas que enmarcan el rostro central ocupen dos de los lugares con más peso en el cuadro, sin embargo, es cosa de la fotógrafa. Vemos, pues, una cara dolorida entre dos rodillas huesudas y, justo debajo de ellas, una oreja y una boca. Un cuadro demoledor, que acrecienta el horror representado. Y es que todas las cuestiones de forma son inmediatamente cuestiones de contenido, y Miller sabía mirar... 
4.5. Guardias capturados

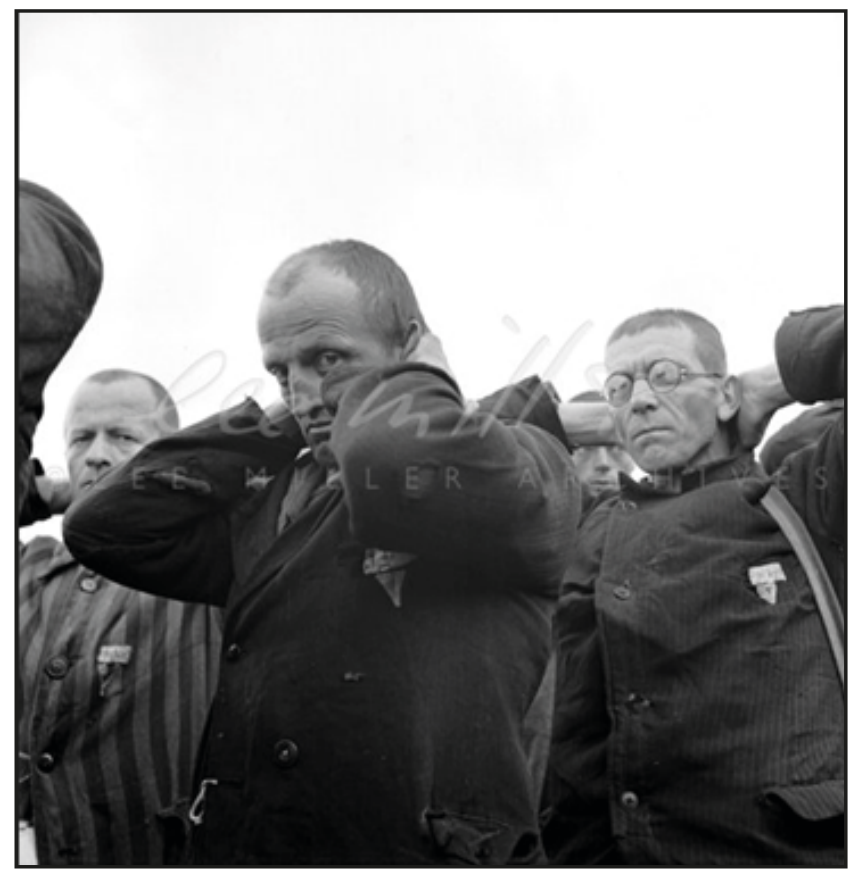

(C) Lee Miller Archives, England 2014. All rights reserved. www.leemiller.co.uk

Lee Miller realizó Guardias capturados vistiendo la ropa de los prisioneros para escapar (Guards Captured Wearing Prisoners Clothing for Escape) en Dachau cuando, de repente, las tornas habían cambiado y los bien alimentados guardias, igual que los escuálidos prisioneros, tuvieron que rebuscar entre los montones de ropa que invadían el campo, en un intento desesperado e inútil de hacerse pasar por lo que no eran.

Cuenta Miller (2005: 182) que la noche del 30 de abril, al llegar al campo de Dachau, los barracones de las SS estaban vacíos. El pequeño canal que delimitaba el campo, sin embargo, estaba lleno de guardias ahogados a los que llevaba la corriente junto con un par de perros. Prisioneros y soldados trataban de pescar algunos de los cuerpos.

Los días siguientes a la liberación, murieron muchos guardias. Unos a manos del ejército, otros a manos de los prisioneros. Hubo también quien se suicidó. Así que los guardias de la foto no dejaban de ser hombres con suerte. Habían sido detenidos cuando pretendían escapar disfrazados de prisioneros, pero seguían vivos.

La imagen se trata de un plano medio de tres guardias. La misma escala, junto con el ligero contrapicado, ya nos dice bastante sobre la distancia que Miller guardaba 
con respecto a sus odiados alemanes. Su presencia se evidencia tanto en las miradas de los guardias como en la repetición de hombres, poses, gestos y miradas, y en las huellas de corte del encuadre -la parte del brazo que vemos en primer plano es la parte de brazo que le falta al guardia en segundo plano-.

Las miradas de los tres guardias son, sin duda, lo más impresionante de la foto. Cada una es diferente. La mirada del guardia en primer plano es la más significativa. Es íntima, y su mensaje resulta mucho más ambiguo que el de las otras dos. Porque, si bien las miradas de los otros dos guardias son inequívocamente duras, esta no lo es. La imagen del guardia central, la mirada directa, el gesto serio, la espalda encorvada, es la imagen de un hombre vencido. La de los otros dos, sin embargo, no lo es; muestran demasiado orgullo, demasiada determinación, y ni rastro de culpa.

Ya hemos visto cómo la cámara de Miller era capaz de ver hombres allí donde las demás únicamente veían cadáveres demacrados. Ahora vemos cómo es capaz de ver hombres incluso donde no hay más que asesinos desalmados, vestidos con las ropas viejas de sus víctimas. Porque el guardia del centro es, sin duda, un hombre. Flanqueado por dos demonios, quizá, pero hombre al fin. Y el hecho de que uno de los perpetradores de semejante crimen sea un hombre es todavía peor que si no lo fuera. Si los nazis hubieran sido animales, diablos, monstruos, los hombres podríamos estar más tranquilos. Pero eran hombres. Didi-Huberman cita a Georges Bataille, quien habla de Auschwitz en estos términos:

Generalmente, en el hecho de ser hombre hay un elemento cargante, repugnante, que es necesario superar. Pero ese peso y esa repulsión nunca han sido tan pesados como después de Auschwitz. Igual que todos nosotros, los responsables de Auschwitz tenían olfato, una boca, una voz, una razón humana, se casaban y tenían hijos: como las Pirámides o la Acrópolis, Auschwitz es el hecho, el signo del hombre (Bataille, 1988: 226,228).

$\mathrm{Y}$ es que tanto las víctimas deshumanizadas como los verdugos inhumanos eran humanos, hombres, mujeres, personas. En las imágenes anteriores vimos que las víctimas son nuestros semejantes, nos identificamos con ellas, sufrimos por su muerte, por su maltrato, por su desnudez. En esta imagen vemos que los verdugos son también nuestros semejantes, y es mucho peor. Más horrible todavía.

\section{Conclusión}

Evidentemente, estas cinco imágenes de Lee Miller no representan el Holocausto en su totalidad. No pueden hacerlo. Como todas, son imágenes precisas pero parciales, extremas pero incompletas. No obstante, representan el horror. Puede que no fueran tomadas por las víctimas; puede que no retrataran el infierno de las cámaras de gas en funcionamiento; pero son imágenes complejas de las cenizas de aquel infierno y su complejidad no es más que una metáfora de la espeluznante complejidad del horror. Miller no cae en la tentación de disfrazar la atrocidad, la desnuda. Y sus imágenes son 
sublimes porque sobrepasan nuestras capacidades, exceden lo imaginable, desbordan los sentimientos, hacen el horror más horrible todavía.

No debemos olvidar que son, además, escenas históricas de las que la fotógrafa fue testigo. Y fue como testigo que registró las víctimas -ausentes, vivas y muertas- y los asesinos de las fotos. Claro que Miller no fue la única que hizo fotografías durante la liberación de los campos -como se ha dicho, Buchenwald y Dachau fueron puntos focales de las visitas oficiales organizadas para dignatarios políticos, oficiales, soldados británicos y americanos, editores, y periodistas y fotógrafos cuyos reportajes ensalzaban la victoria aliada y la heroicidad de sus soldados-, pero sus fotos son diferentes. Ella era ahora corresponsal de guerra, hacer estas fotos era su misión, pero la sensibilidad de su mirada le impedía ver en los lagers historias de vencedores y vencidos. De ahí que la aportación más importante de este trabajo sea esta: quizá sólo una mirada surrealista pueda representar lo irrepresentable.

\section{Referencias bibliográficas}

ADORNO, T. W. (1949). "Cultural Criticism and Society". En Prisms. Cambridge: MIT Press, 1983, pp. 17-34.

ARENDT, H. (1951). Los origenes del totalitarismo. Madrid: Taurus, 1998.

BARTHES, R. (1980). La cámara lúcida. Barcelona: Paidós, 1989.

BURKE, C. (2007). Lee Miller: A Life. Chicago: University of Chicago Press.

BURUCÚA, J. E. y KWIATKOWSKI, N. (2014). "Cómo sucedieron estas cosas". Representar masacres y genocidios. Buenos Aires: Katz Editores.

CAMPBELL, J. (1972). Los mitos. Su impacto en el mundo actual. Barcelona: Kairós, 1994.

DIDI-HUBERMAN, G. (2003). Imágenes pese a todo. Memoria visual del Holocausto. Barcelona: Paidós, 2004.

(2015). Sortir du noir. Paris: Editions de Minuit.

ECO, U. (2004). Historia de la belleza. Barcelona: Lumen.

(1992). "Entre el autor y el texto". En ECO, Umberto. Interpretación y sobreinterpretación. Madrid: Cambridge University Press, 1997, pp. 80-103.

FRANKL, V. (1946). El hombre en busca de sentido. Barcelona: Herder, 2004.

LANZMANN, C. (1985). Shoah. Francia: Les Films Aleph et Ministère de la Culture de la Republique Française.

LEVI, P. (1957). Si esto es un hombre. Barcelona: El Aleph, 1995. (1986). Los hundidos y los salvados. Barcelona: El Aleph, 2002.

LIEBMAN, S. (2007). "An Introduction to Claude Lanzmann's Shoah". En Claude Lanzmann's Shoah: Key Essays. Oxford: Oxford University Press.

MIGUEL SÁEZ DE URABAIN, A. (2015). “¿Puede la fotografía mostrar lo inimaginable? El debate en torno a la representación de la Shoah". En Fotocinema. Revista cientifica de cine y fotografia, 10, pp. 233-262. 
MILLER, L. (2005). Lee Miller's War, ed. Antony Penrose. New York: Thames \& Hudson.

SIM, L. (2009). "A different war landscape: Lee Miller's war photography and the ethics of seeing". En Modernist Cultures, $\mathrm{n}^{\circ}$ 4, pp. 48-66.

SLIWINSKI, S. (2010). "Visual Testimony: Lee Miller's Dachau". En Journal of Visual Culture, vol. 9 (3), pp. 389-408.

SONTAG, S. (2003). Ante el dolor de los demás. Madrid: Alfaguara.

TALENS, J. et. Al. (1980). Elementos para una semiótica del texto artístico. Madrid: Catedra.

WAJCMAN, G. (1998). El objeto del siglo. Buenos Aires: Amorrortu, 2002.

\section{Notas}

1 Bourke-White entró en Buchenwald en marzo de 1945, con el Tercer Ejército del general Patton. Sus fotografías aparecieron publicadas en la revista Life y, posteriormente, en su propio libro sobre la liberación de Alemania, Dear Fatherland, Rest Quietly, 1945.

2 En su biblioteca de imágenes (Picture Library) el Lee Miller Archive muestra al público casi 2.500 imágenes fotográficas de la artista y unas 500 hojas de contacto. De Alemania hay, excluyendo estas últimas, 380 fotografías, de las que 30 pertenecen a Buchenwald y 44 a Dachau.

3 En la Shoah de Lanzmann, los supervivientes de Vilna Motke ZaÏdl e Itzhak Dugin narran cómo tuvieron que desenterrar los cadáveres de sus vecinos cavando con sus propias manos en el bosque de Ponari. Cuentan que, al principio, no podían contener las lágrimas, lo que enfurecía a los alemanes, que les azotaban hasta casi la muerte: "Los alemanes", dicen, "incluso nos prohibieron usar las palabras 'cadáver' o 'víctima'. (...) nos obligaban a referirnos a los cuerpos como figuren, es decir, como marionetas, como muñecos, o como schmattes, que significa 'trapos'. 